\title{
DEVELOPMENT OF ENTREPRENEURSHIP EDUCATION TEACHING MATERIAL BASED ON THE NATIONAL RESILIENCE AND AMARE CULTURE
}

\author{
Yosua Damas Sadewo ${ }^{1)}$, Pebria Dheni Purnasari ${ }^{2)}$, Bella Ghia Dimmera ${ }^{3)}$ \\ ${ }^{1)}$ STIM Shanti Bhuana, Bengkayang, Indonesia \\ E-mail: yosua.damas@shantibhuana.ac.id \\ ${ }^{2)}$ STIM Shanti Bhuana, Bengkayang, Indonesia \\ E-mail: pebria.dheni@shantibhuana.ac.id \\ ${ }^{3)}$ STIM Shanti Bhuana, Bengkayang, Indonesia \\ E-mail: bellaghia@shantibhuana.ac.id
}

\begin{abstract}
The development of teaching materials is important to create a learning process that suits the needs of STIM Shanti Bhuana. The Entrepreneurship Study Program of STIM Shanti Bhuana has not yet possessed teaching materials that represent the characteristics of the institution, i.e. national resilience and Amare culture. Therefore, needed the development of a valid teaching material that can improve students' learning outcomes, and has characteristics that can be used. Borg and Gall's model of development is employed in this study which is summarized into three major steps to ease the study. The steps include the study of introduction, product development, and product validation. This study shows that this developed teaching material is valid. The result is obtained through the analysis upon the validation forms. From 9 validations, the score of 4.49 is obtained. The value means that the teaching material is appropriate and can be used. The analysis result on the learning mastery, after the students attend the classes integrating the teaching material, is $75 \%$. Through the $\mathrm{N}$-gain exam, it is known that there is an improvement between the pre-test and post-test with a value of 0.40 . The percentage value of the improvement is $33.33 \%$. The characteristics of the development of the National Resilience and Amare Culture-Based Entrepreneurship Education, based on the questionnaire, shows that the developed teaching material provides a good effect on the students. Through the measurement on the score from the questionnaire, it is gained the value of 83.8. Therefore, it can be concluded that the developed teaching materials are valid, can improve students' learning outcomes, and are easily used by the students.
\end{abstract}

Keywords: Teaching Material; Entrepreneurship Education; National Resilience; Amare Culture

\section{INTRODUCTION}

Becoming one of the programs in Sekolah Tinggi Ilmu Manajemen Shanti Bhuana (STIM Shanti Bhuana), the entrepreneurship program focuses on the entrepreneurship skills of the students practiced through the subjects of entrepreneurship education. To create an excellent entrepreneurship education, many efforts are needed. One of the efforts is to develop an applicative teaching material allowing the students to improve their skills which will be used as they enter the professional world. Therefore, the development of the teaching material is needed to create a directed learning process $(\mathrm{HB}, 2012)$. Teaching material can be defined as a set of learning tools supporting the learning process. The availability of the teaching material becomes the source needed during learning (Majid, 2012). In teaching material, embedded are sciences or ideas gained through the result of research, observation, and experience actualization that can be used to support the learning process (Prastowo, 2012). To develop appropriate teaching materials, a need analysis is needed upon the development of the teaching materials. The availability of an appropriate teaching material which is in line with the learning need will finally create a good learning outcome as well.

The entrepreneurship program is expected to prepare the students to have experience in entrepreneurship (Erickson \& Laing, 2016). Entrepreneurship education is delivered as an 
effort to create entrepreneurs who can keep up with the development of overtimes (Sadewo, 2018). The experience was created through the learning process by using applicative teaching material that allows the students to improve their skills in entrepreneurship. Based on the reflection done along with the lecturers of the Entrepreneurship Program in STIM Shanti Bhuana, it is found out that many students are only good at the theory, but still lacking in term of practicality. The students' skills in entrepreneurship are also identified as less innovative, which is proven by so many entrepreneurship program proposals which are similar one group to another. The proposals are supposed to be different so that the innovation and creativity can be identified. Besides, in the teaching materials evaluation, the characteristics from STIM Shanti Buana, which are Amare culture and national resilience, have not been found. Amare culture is an adaptation of Catholic characteristics which shapes religious and loving individual (the statute of STIM Shanti Bhuana). For STIM Shanti Bhuana, Amare Culture becomes an important thing that needs to be cultivated. It is expected that the students are devout to God so that they can do their tasks and responsibilities honestly and responsibly. Meanwhile, national resilience is promoted because Entrepreneurship Program of STIM Shanti Bhuna was founded in Bengkayang.

Bengkayang is an area that still needs to be developed. Until the middle of 2019, this region was classified as a $3 \mathrm{~T}$ (the frontier, outermost and remote/ in Indonesia is Terdepan, Terluar, dan Tertinggal) region. This status determined through Presidential Regulation No. 131/2015, clarified in Presidential Regulation No. 21/2018 on the National Strategy for Accelerating Development of Less-Developed Regions in 2015-2019, shows that conditions in Bengkayang are not as advanced as those in urban areas (Purnasari \& Sadewo, 2019). Moreover, it also becomes the border region of IndonesiaMalaysia so that the national resilience is vital. Considering such a situation, STIM Shanti Bhuana, which is located in the border area, needs to nurture the students' nationalism as prospective young entrepreneurship who can later build this region. Observing those things above, it is needed to develop teaching material that is more practical and also includes Amare Culture and national resilience. The development of this teaching material aims to create a learning process that supports the students to have entrepreneurship skills, Amare culture, and national resilience. Derived from the reasons above, this study aims to: (1) gain a valid result of the development of national resilience and Amare culture-based entrepreneurship education teaching material development; (2) know the learning outcome by using the national resilience and Amare culture-based entrepreneurship education; (3) know the characteristics of the national resilience and Amare culture-based entrepreneurship education.

\section{METHODOLOGY}

This study is development research that aims to develop teaching materials for entrepreneurship education based on national resilience and Amare culture. It employs the development model proposed by Borg and Gall. The 10 steps of the Borg and Gall's development model are further grouped into 3 main steps to facilitate research: a preliminary study, product development, and product validation and trials.

Preliminary studies were carried out by collecting and analyzing information about problems and needs required for entrepreneurship learning. The product development phase was carried out by preparing a draft product design that is teaching materials on entrepreneurship education based on Amare culture and national resilience. The validation stage involved (1) validation by experts, and (2) validation by lecturers in the Entrepreneurship Study Program. After a valid product was obtained, the developed teaching materials were tested and distributed.

The analysis included initial tests (i.e. homogeneity, normality, and item test analysis), and final test (i.e. the teaching materials validation analysis). The teaching materials validation analysis involved experts and employed validation sheets.

\section{RESULTS AND DISCUSSION}

\section{A. Result}

\section{Teaching Material's Validation Result}

The developed teaching material was validated to know its appropriateness before being used in the learning process in the entrepreneurship program. The teaching material, entitled "National Resilience and Amare Culture-Based Entrepreneurship Education", was analyzed by using a descriptive-quantitative method. Eight validators were evaluating the teaching material's appropriateness whose expertise is on entrepreneurship, national resilience, Amare Culture, and biblical theology. The validation result is presented in Table I.

TABLE I

VALIDATION RESUlTS OF TEACHING MATERIALS

\begin{tabular}{cccccccccc}
\hline Validator & \multicolumn{1}{c}{ Statement } & Score \\
\cline { 2 - 9 } & $\mathbf{1}$ & $\mathbf{2}$ & $\mathbf{3}$ & $\mathbf{4}$ & $\mathbf{5}$ & $\mathbf{6}$ & $\mathbf{7}$ & $\mathbf{8}$ & \\
\hline 1 & 5 & 5 & 4 & 5 & 4 & 4 & 4 & 5 & 4.50 \\
2 & 5 & 5 & 4 & 4 & 4 & 5 & 5 & 5 & 4.63 \\
3 & 5 & 5 & 5 & 5 & 5 & 5 & 5 & 5 & 5.00 \\
4 & 5 & 4 & 5 & 4 & 5 & 5 & 5 & 5 & 4.75 \\
5 & 5 & 4 & 4 & 3 & 4 & 4 & 4 & 4 & 4.00 \\
6 & 5 & 4 & 3 & 5 & 4 & 5 & 5 & 5 & 4.50 \\
7 & 4 & 4 & 4 & 4 & 4 & 4 & 4 & 4 & 4.00 \\
8 & 5 & 4 & 4 & 4 & 4 & 4 & 4 & 4 & 4.13 \\
9 & 5 & 5 & 5 & 5 & 4 & 5 & 5 & 5 & 4.88 \\
\hline \multicolumn{10}{c}{ Average Score }
\end{tabular}

Assessment criteria toward the teaching material including its conclusion are based on Table II. According to the validation analysis result demonstrated in Table II, it can be known that the validation score result is 4.49 . Relying on Table II, the mentioned value lies in the range of 4.00-5.00 regarded as a "Very Appropriate" in which the conclusion is "teaching material with no revisions can be used". However, a few revisions in the teaching material were done with the help of notes given by the validators. 
TABLE II

ASSESSMENT CRITERIA OF TEACHING MATERIAL VALIDATION

\begin{tabular}{|c|c|c|}
\hline Average Score & Criteria & Conclusion \\
\hline $1.00 \leq \mathrm{S} \leq 1.90$ & $\begin{array}{c}\text { Less } \\
\text { Appropriate }\end{array}$ & $\begin{array}{l}\text { Teaching material } \\
\text { cannot be used yet, } \\
\text { and still requires more } \\
\text { consultation }\end{array}$ \\
\hline $2.00 \leq \mathrm{S} \leq 2.90$ & $\begin{array}{c}\text { Quite } \\
\text { Appropriate }\end{array}$ & $\begin{array}{l}\text { Teaching material } \\
\text { with many revisions } \\
\text { can be used }\end{array}$ \\
\hline $3.00 \leq \mathrm{S} \leq 3.90$ & $\begin{array}{c}\text { Quite } \\
\text { Appropriate }\end{array}$ & $\begin{array}{l}\text { Teaching material } \\
\text { with little revisions } \\
\text { can be used }\end{array}$ \\
\hline $4.00 \leq S \leq 5.00$ & $\begin{array}{c}\text { Very } \\
\text { Appropriate }\end{array}$ & $\begin{array}{l}\text { Teaching material } \\
\text { with no revisions can } \\
\text { be used }\end{array}$ \\
\hline
\end{tabular}

\section{Teaching Material's Efficiency}

The efficiency of the teaching material was assessed from students' results after joining the lecture using the developed teaching material. The material is considered as effective if it is understandable, and if many students have passed the passing grade. The assessment aimed to analyze students' understanding was done using an evaluation test. Besides, the success of utilizing the developed material was measured by a ratio between pre-test and post-test scores calculated by using the $\mathrm{N}$-Gain test. The $\mathrm{N}$-gain test was used to measure the improvement related to students' learning outcomes in terms of cognitive skill. Before conducting the $\mathrm{N}$-gain test, provided are the descriptions of the students' evaluation or post-test scores after attending courses that used the teaching material entitled "National Resilience and Amare Culture-Based Entrepreneurship Education”.

TABLE III

STUDENTS' EvaluATION SCORE

\begin{tabular}{ccl}
\hline $\begin{array}{c}\text { Students } \\
\text { Code }\end{array}$ & Score & \multicolumn{1}{c}{ Description } \\
\hline SP_1 & 55 & Not yet mastered well \\
SP_2 & 80 & Good mastery \\
SP_3 & 70 & Good mastery \\
SP_4 & 55 & Not yet mastered well \\
SP_5 & 80 & Good mastery \\
SP_6 & 85 & Good mastery \\
SP_7 & 75 & Good mastery \\
SP_8 & 70 & Good mastery \\
SP_9 & 85 & Good mastery \\
SP_10 & 50 & Not yet mastered well \\
SP_11 & 75 & Good mastery \\
SP_12 & 70 & Good mastery \\
\hline Highest & & $\mathbf{8 5}$ \\
Score & & $\mathbf{5 0}$ \\
\hline Lowest & & $\mathbf{7 0 . 8 3}$ \\
Score & & \\
\hline Average & & \\
Score & & \\
\hline
\end{tabular}

Students' learning outcomes shown in Table III are obtained after the students attended lectures implementing the developed materials. Table 3 reveals that there are three out of 12 students who did not pass the course, with the rest nine students were considered as those who passed it. According to those scores, it can be concluded that the students' learning mastery after attending the course using the material has reached $75 \%$. This mastery has fulfilled the indicator of learning mastery determined by a lecturer with a standard indicator of $70 \%$ of students who passed the course. A diagram to illustrate the learning mastery is presented in Fig. 1 .

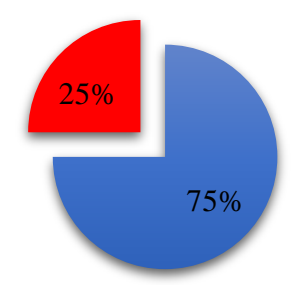

- Good mastery $\quad$ Not yet mastered well

Fig. 1 Diagram of students' learning mastery percentage

After gaining the evaluation score, the post-test one, the $\mathrm{N}$ gain test was carried out to identify the score improvement of the students' learning outcomes. The pre-test and post-test scores before the $\mathrm{N}$-gain test can be seen in Table IV.

TABLE IV

STUdENTS' PRE-TEST AND POST-TEST SCORE

\begin{tabular}{ccc}
\hline Students' Code & Post-test Score & Pre-test Score \\
\hline SP_1 & 55 & 35 \\
SP_2 & 80 & 65 \\
SP_3 & 70 & 60 \\
SP_4 & 55 & 35 \\
SP_5 & 80 & 60 \\
SP_6 & 85 & 60 \\
SP_7 & 75 & 55 \\
SP_8 & 70 & 45 \\
SP_9 & 85 & 65 \\
SP_10 & 50 & 35 \\
SP_11 & 75 & 50 \\
SP_12 & 70 & 50 \\
\hline Highest Score & $\mathbf{8 5}$ & $\mathbf{6 5}$ \\
\hline Lowest Score & $\mathbf{5 0}$ & $\mathbf{3 5}$ \\
\hline Average Score & $\mathbf{7 0 . 8 3}$ & $\mathbf{5 1 . 2 5}$ \\
\hline
\end{tabular}

The pre-test and post-test scores displayed in Table 4 have shown different results. The better result is gained after the students were taught by using the developed learning material It can be seen from the post-test score which was higher than the pre-test one. To determine the improvement of students' learning results, the $\mathrm{N}$-gain test was carried out as follows.

The $\mathrm{N}$-gain test has a result of 0.40 , defined as the "average" category. In conclusion, the improvement of students' learning outcomes after joining the course using the "National Resilience and Amare Culture-Based Entrepreneurship Education" material has shown a significant enhancement with a score of 0.40 . The percentage of students' learning mastery from their pre-test and post-test scores are displayed in Fig. 2.

The comparison of the students' who had a good mastery and those who have not mastered well yet presented in Figure 2 has shown that their mastery in the post-test is higher than the one in the pre-test. The result also indicates an improvement related to learning mastery which is $33.33 \%$ in 
percentage. By using the $\mathrm{N}$-gain analysis test, the increase is considered significant.

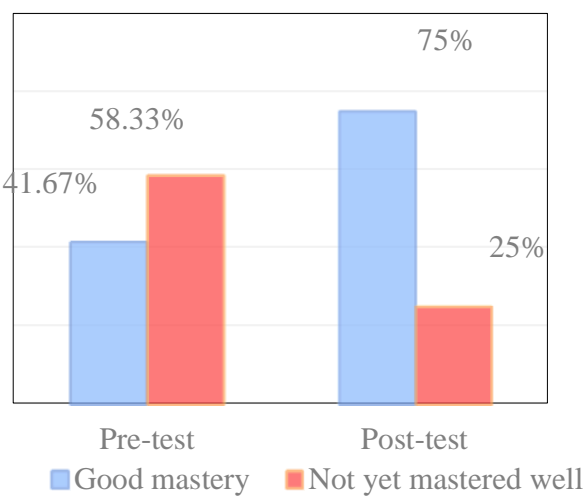

Fig. 2 Diagram of students' learning mastery

\section{Teaching Material's Characteristics}

The characteristics of teaching material of "National Resilience and Amare Culture-Based Entrepreneurship Education" were measured using a list of the questionnaire which represented students as the users of the teaching material in the learning process. The questionnaire was created using the Likert scale in which the students merely responded to given statements. Moreover, there were five options related to the responses, which were: strongly agree, agree, hesitate, disagree, and strongly disagree. The list of the questionnaire aimed to analyze the teaching materials' characteristics can be found in Table V.

TABLE V

QuESTIONNAIRE STATEMENTS TOWARDS TEACHING MATERIALS' CHARACTERISTICS

\begin{tabular}{|c|c|}
\hline No & Statements \\
\hline & The teaching material of "National Resilience and Amare \\
\hline 1. & $\begin{array}{l}\text { Culture-Based Entrepreneurship Education" being used in } \\
\text { the course is understandable }\end{array}$ \\
\hline 2. & Students have no difficulty in using the teaching material \\
\hline 3. & $\begin{array}{l}\text { The language used in the teaching material is } \\
\text { understandable }\end{array}$ \\
\hline 4. & Exercises in the teaching material can be done easily \\
\hline \multirow[t]{3}{*}{5.} & Students are pleased in learning using "National \\
\hline & Resilience and Amare Culture-Based Entrepreneurship \\
\hline & Education" material \\
\hline 6. & The teaching material used in the course is interesting \\
\hline 7. & $\begin{array}{l}\text { The teaching material can improve students' interests in } \\
\text { attending the class }\end{array}$ \\
\hline 8. & $\begin{array}{l}\text { Students can remember the material easily when learning } \\
\text { it }\end{array}$ \\
\hline 9. & $\begin{array}{l}\text { Relation of Amare Culture with entrepreneurship field can } \\
\text { be understood well with the presence of the teaching } \\
\text { material }\end{array}$ \\
\hline 10. & $\begin{array}{l}\text { Relation of national resilience with entrepreneurship field } \\
\text { can be understood well with the presence of the teaching } \\
\text { material }\end{array}$ \\
\hline
\end{tabular}

Data related to the questionnaire result is displayed in Table VI.
TABLE VI

QUESTIONNAIRE RESULTS

\begin{tabular}{lccccccccccc}
\hline $\begin{array}{c}\text { Students } \\
\text { Code }\end{array}$ & $\mathbf{1}$ & $\mathbf{2}$ & $\mathbf{3}$ & $\mathbf{4}$ & $\mathbf{5}$ & $\mathbf{6}$ & $\mathbf{7}$ & $\mathbf{8}$ & $\mathbf{9}$ & $\mathbf{1 0}$ & \multirow{2}{*}{ Score } \\
\hline SP_1 & 4 & 4 & 5 & 4 & 4 & 3 & 4 & 3 & 4 & 4 & 78 \\
SP_2 & 4 & 4 & 4 & 3 & 4 & 4 & 4 & 4 & 4 & 4 & 78 \\
SP_3 & 4 & 4 & 4 & 4 & 4 & 5 & 4 & 4 & 5 & 5 & 86 \\
SP_4 & 4 & 4 & 4 & 4 & 4 & 5 & 4 & 4 & 4 & 4 & 82 \\
SP_5 & 5 & 5 & 5 & 4 & 4 & 4 & 5 & 4 & 4 & 5 & 90 \\
SP_6 & 5 & 5 & 5 & 5 & 5 & 4 & 4 & 4 & 5 & 5 & 94 \\
SP_7 & 4 & 4 & 4 & 5 & 4 & 5 & 4 & 4 & 4 & 4 & 84 \\
SP_8 & 4 & 4 & 4 & 4 & 4 & 4 & 4 & 4 & 4 & 4 & 80 \\
SP_9 & 4 & 4 & 4 & 4 & 4 & 5 & 4 & 4 & 5 & 5 & 86 \\
SP_10 & 4 & 4 & 4 & 4 & 5 & 4 & 4 & 4 & 4 & 5 & 84 \\
SP_11 & 4 & 4 & 4 & 4 & 4 & 4 & 5 & 4 & 4 & 4 & 82 \\
SP_12 & 4 & 4 & 4 & 4 & 4 & 4 & 4 & 4 & 4 & 5 & 82 \\
\hline
\end{tabular}

The questionnaire result as presented in Table 6 has shown an average score of 83.3. The score can be classified as a proper one. Furthermore, the result also confirmed that the teaching material's characteristics being used got positive responses from the students. It was proven by quite a high average score. In general, each statement in the questionnaire got positive responses. An analysis of each statement has revealed that the students found no difficulties in using the teaching material, and they were interested and pleased in attending the class which used the designed teaching material. A correlation between national resilience and Amare Culture which represents the institution was also applied more easily in the entrepreneurship concept by using the description inside the teaching material.

\section{B. Discussion}

In general, the result of data analysis regarding the validity, learning mastery, and characteristics of the teaching material has shown a good result. The teaching material validated by nine expert validators has shown a score of 4.49 . The grade was categorized as appropriate. Therefore, after going through some validation process, the teaching material entitled "National Resilience and Amare Culture-Based Entrepreneurship Education" was considered as valid and can be used as the source of learning.

Therefore, valid teaching material can be used as a reference during the learning activity. The connection between national resilience and Amare Culture in the field of entrepreneurship may direct the students to have the spirit of nationalism, and behave according to the Amare Culture's characteristics. Moreover, it was known that the N-gain test's score was 0.40 . This $\mathrm{N}$-gain test was applied for measuring the improvement value of learning outcomes. The $\mathrm{N}$-gain test result also demonstrated substantial improvement. Then, an analysis of the learning mastery percentage was also conducted. The ratio also showed that the post-test' score was higher than the pre-test, which has a percentage of $33.33 \%$. The total number of students who passed the post-test was nine out of 12 people. It was a greater number than the ones 
from the pre-test, which were only five out of 12 students. It implies that the use of the teaching material in the learning process has caused positive influence as indicated by the increase in learning outcomes. Besides, the teaching material was designed following the students' needs by using a language adjusted with students' comprehension skills. It can be seen from the questionnaire result which stated that the material could be used by the students well. They also could understand and use the material without any problems.

The questionnaire result has reached a high score, which was 83.8 . The result was gained from the average score in the questionnaire filled out by 12 respondents. The respondents consisted of the students who used teaching material throughout the course. The result has approved that the use of teaching material was beneficial to the students' learning mastery. The grade from the post-test was higher than the one from post-test. This study result supports research conducted by (Dewi \& Irsan, 2017) in which the developed teaching material can create more directed learning. Besides, the study result performed by (Fitriati \& Hermiati, 2011) also explains that entrepreneurship skills can be sharpened through an entrepreneurship program. This is in line with the teaching material used in this research, in which the entrepreneurship skill can be polished through real practices. Furthermore, the study result is also consistent with the one conducted by (Hakim, 2010) which showed that the material can be used as the support material in the learning process. Lastly, the research finding is also coherent with a study of (Premand, Brodmann, Almeida, Grun, \& Barouni, 2016)which mentioned that entrepreneurship education in the collegelevel requires a program that can develop an entrepreneurship skill. The program can be in the form of courses supported by appropriate learning materials. That said, the use of "National Resilience and Amare Culture-Based Entrepreneurship Education" teaching material could be beneficial in achieving the effective learning process.

\section{IV.CONCLUSIONS AND SUGGESTIONS}

The analysis result shows that the teaching materials developed are valid with a score of 4.49. Meanwhile, through the N-Gain test, it can be seen that there is a significant increase in student learning outcomes after attending lectures using the developed teaching materials. This significant improvement indicates that the teaching materials developed have positive impacts on students' learning outcomes. Besides, the teaching materials are proven to be used in ease by the students as it gained a score of 83.8 from the distributed questionnaires. Therefore, it can be concluded that the developed teaching materials are valid, can improve students' learning outcomes, and are easily used by the students.

Concerning the research result and conclusion, it is expected that the teaching material can be developed better to meet the needs of the entrepreneurship course. Besides, it is also hoped that this material can also be a reference for the students to deeply understand the entrepreneurship field associated with national resilience and Amare Culture.

\section{REFERENCES}

Dewi, M., \& Irsan. (2017). Pengembangan Buku Ajar Kewirausahaan pada Materi Menjual Produk atau Jasa Berbasis Bisnis On Line untuk Mahasiswa FKIP UPI YPTK Padang. Majalah Ilmiah UPI YPTK, 24(2), 251-260.

Erickson, S. M., \& Laing, W. (2016). The Oxford MBA: A Case Study In Connecting Academia with Business. Journal of Entrepreneurship Education, 19(1), 1-8.

Fitriati, R., \& Hermiati, T. (2011). Entrepreneurial Skills and Characteristics Analysis on the Graduates of the Department of Administrative Sciences, FISIP Universitas Indonesia. Jurnal Ilmu Administrasi Dan Organisasi Journal of Administrative Sciences \& Organization, 17(3), 262-275.

Hakim, A. (2010). Model Pengembangan Kewirausahaan Sekolah Menengah Kejuruan ( SMK ) Dalam Menciptakan Kemandirian Sekolah. Riptek, 4(1), 114.

HB, F. P. M. (2012). Pengembangan Bahan Ajar Science Untuk Mendukung Program Kreativitas Mahasiswa. Jurnal Penelitian Pendidikan, 29(2), 101-108.

Majid, A. (2012). Perencanaan Pembelajaran. Bandung: PT. Remaja Rosdakarya.

Prastowo, A. (2012). Panduan Kreatif membuat Buku ajar Inovatif. Jogjakarta: DIVA Press.

Premand, P., Brodmann, S., Almeida, R., Grun, R., \& Barouni, M. (2016). Entrepreneurship Education and Entry into Self-Employment Among University Graduates. World Development, 77, 311-327. https://doi.org/https://doi.org/10.1016/j.worlddev.20 15.08.028

Purnasari, P. D., \& Sadewo, Y. D. (2019). Pendidikan Ketahanan Sosial dan Ekonomi dalam Meningkatkan Karakter Nasionalisme dan Wawasan Bela Negara. In Seminar Nasional Kesadaran Bela Negara dalam Rangka Mencegah Disintegrasi Bangsa di Era Revolusi Industri 4.0 (p. 64). Bogor: Universitas Pertahanan.

Sadewo, Y. D. (2018). Hambatan dan Tantangan Program Studi Kewirausahaan di Wilayah Perbatasan. MABIS, $8(1)$. 